\title{
The Applying of K-W-L (Know-What-Learned) Strategy Through the Campus Active Bowling Models to Improve Student'S Activities and Achievement in Class VII.C Junior High School (SMP) Negeri 8 Padang
}

\author{
Syafniwati ${ }^{1 *}$ Yuni Ahda ${ }^{1}$ Ghery Priscylio ${ }^{2}$
}

\author{
${ }^{1}$ Biology Education Post Graduate Program Math and Natural Science Faculty Universitas Negeri Padang Padang, \\ Indonesia \\ ${ }^{2}$ Biology Department Math and Natural Science Faculty Andalas University Padang, Indonesia \\ *Corresponding author. Email: syafniwatibsmpn8@gmail.com
}

\begin{abstract} VII.C secondary high school 8 of Padang. ( $K-W-L)$, Science Education, Secondary High School

\section{INTRODUCTION}

Science Learning in Junior High School (SMP) / Madrasah Tsanawiyah (MTs) class VII refers to the concept of the 2013 curriculum which requires students to be competent in cognitive, affective and psychomotor aspects. The 2013 curriculum focuses on the formation of competencies and characters of students in the form of a blend of knowledge, skills and attitudes that students can demonstrate as a form of understanding of the concepts they learn contextually $[3,5,10]$. Basically what underlies learning activities in the 2013 curriculum is a scientific approach (scientific approach), although it is actually not new, because the scientific approach to the KBK (Competency Based Curriculum) already exists, but the terms are different. In Permendikbud Number 81A of 2013, the learning process consists of five main lessons namely: observing, asking questions, gathering information, associating, and communicating.
\end{abstract}

This study aims to describe the increase in activities and student learning outcomes with the implementation of KWL (Know-Want-Learned) strategy through the campus active bowling models. This classroom action research was conducted in two cycles. Each cycle consists of 4 stages, namely planning, action, observation and reflection. The research subjects were students of class VII.C secondary high school 8 of padang.. The research instruments used were student activity observation sheets, student competence observation sheets in the cognitive, affective and psychomotor domains (learning outcomes). The data of this study were analyzed qualitatively and quantitatively. The results of the first and second cycle data analysis applied the K-W-L (Know-Want-Learned) strategy through the campus active bowling learning model. In the first cycle student activity averaged $68.75 \%$, the second cycle averaged $89.86 \%$. In the cognitive domain, the first cycle averages $75 \%$ and the second cycle averages $100 \%$. In the affective domain the first cycle averaged $78.61 \%$ and the second cycle was $86.52 \%$ and the psychomotor domain in the first cycle averaged $95.48 \%$ and the second cycle averaged $99.33 \%$. Based on the results obtained it can be concluded that the adoption of the KWL (Know-Want-Learned) strategy approach through campus bowling active learning models can improve student learning activities, thus providing a positive impact on improving student learning outcomes in class

KeyWord: Action Research, Biology Education, Bowling Campus, Integrated Science, Know-Want-Learned

Science learning in junior high school is an integration of the concepts of chemistry, physics and biology which is often also called integrated science learning [8], so it is hoped that for every knowledge taught, the learning must continue until the student is skilled in presenting the knowledge he masters concretely and abstractly, and behaves as a being who is grateful for the gift of the universe given to him through responsible utilization. Integrated Science learning should be able to provide direct experience to students so as to increase the ability to construct, understand, and apply concepts that have been learned [15].

From the author's experience teaching science in class VII $\mathrm{C}$, some of the students have less ability in the activity of asking, expressing ideas or opinions in a discussion. More students are silent and wait for students who are active only to express opinions and answer questions. The author considers the need to improve their ability to master subject matter through reading comprehension and other process skills that will provide learning experiences for students. So that the implementation of the learning 
process can take place better, the writer has tried to motivate students not to be embarrassed to answer or ask questions. The lack of this activity does have an impact on student learning outcomes that get grades below the completeness set by the school that is 80 . The low activity of asking students is a problem that the writer has to find a solution for so that the learning process can take place well so that student learning outcomes will improve. To increase the activities and student learning outcomes can be done by applying the KWL (Know-Want- Learned) strategy. The selection of KWL strategy is because in the implementation of this strategy students are trained to be able to raise curiosity, so the activity of asking questions and communicating with fellow friends both in group discussions and class discussions is well conveyed $[2,12,13]$.

According to Ogle [7], KWL stands for: $\mathrm{K}$ (know) What is known (before reading), W (want) What is known (before reading), $\mathrm{L}$ (learned) What is known (after reading). The KWL strategy developed by Ogle helps teachers bring to life the students' background knowledge and interest in a topic. The KWL strategy involves three basic steps that guide students in giving a way about what they already know, determining what they want to know, and recalling what they learned from reading [4,9].

The active learning model chosen is the bowling campus which can provide a memorable learning experience for students. This type of active learning is an alternative to material review. This active learning model allows the teacher to evaluate the extent to which students have mastered the material, reinforced, explained, and sought the main points [11]. This can be done in the form of pertoy fighting speed answering questions. The advantage of active learning in the type of bowling campus is that it can create learning that is PAIKEM (active, innovative, creative, effective, and fun learning). The merging of the KWL strategy with active learning of bowling campus is to complement each other, the shortcomings of the KWL strategy are that the teacher cannot be sure whether students have been able to understand all the learning materials that day. A strategy for reviewing the material while evaluating student understanding can be done with active bowling campus learning. If with the KWL strategy students who are passive and shy have not been able to actively participate in their groups then through the application of active learning the bowling campus makes passive students become more active in learning. Students who are usually afraid, shy and reluctant to ask questions directly to the teacher can ask questions through friends in the group.

\section{MATERIALS AND METHODS}

\subsection{Method}

The type of research to be carried out is classroom action research. Classroom action research (CAR) is research conducted by teachers in their own classes through selfreflection with the aim of improving learning [6]. This research was conducted at SMP Negeri 8 Padang. In the even semester starting from April 4, 2016 to May 4, 2016
$2015 / 2016$ school year, in line with the on going learning process. The research subjects were students of class VII.C, SMP Negeri 8 Padang. The number of students is 24 students, consisting of 14 female students and 10 male students

\subsection{Researcs Procedure}

This research was conducted in the form of cycles, one cycle consisting of four stages, namely: Planning (planning), action (action), observation (observation) and reflection (reflection). Cycle I

a. The planning stage. At the planning stage, the activities carried out by researchers are as follows:

1) Prepare and design learning tools in the form of, syllabus, Lesson Plan (RPP), work sheet, and evaluation sheets

2) Prepare student activity sheets and student learning outcomes assessment sheets.

3) Plan group assignments that students must work on

4) Develop KWL instruments to be filled out by students.

5) Arrange index card instruments for each group of students.

6) Arrange student study groups

b. I mplementation phase The activities carried out by researchers are as follows:

1) the teacher greets

2) the teacher gives information to students about the learning phase using the KWL strategy and the active bowling campus learning model that students will go through.

3) the teacher gives apperception

4) the teacher provides motivation

5) the teacher gives the KWL sheet to be filled out by students

6) the teacher asks students to fill in column $\mathrm{K}$, about what they know from the topic they are going to study.

7) the teacher asks students to discuss what they want to learn from the topic of the day's lesson. The teacher guides students to prioritize questions about what they want to know and write them down in column W.

8 ) the teacher tells students to read books or do activities according to the topic of the day's study.

9) the teacher tells students to write what they have read or discussed and what they have learned in column L.

10) the teacher activates students to know students' understanding of the subject matter through the active learning model of the bowling campus

11) the teacher asks questions and students will answer by brandishing the index cards they have

12) groups of students who can answer quickly and correctly write down their scores on the index card.

13) $\mathrm{T}$ he teacher gives an award to the group of students who get the best score.

c. Observation and observation stages Observation of student activities and teacher activities in the learning process is assisted by two collaborators by filling out the activity sheets provided. Collaborators also make field notes of facts that occur in the field that are not contained in the activity sheet. This activity was also carried out 
recording video shooting to facilitate collaborators and researchers in making observation.

d. Analysis and reflection stage In the reflection activity, the activities carried out are:

1) Analyze findings when observing and analyzing weaknesses and learning success using the implementation of the KWL strategy and the active Bowling Campus learning model.

2) Reflect on learning using the implementation of the KWL strategy and the Bowling Campus active learning model

3) Reflect on student learning activities and outcomes The results of data reflexes carried out in cycle I are used as a reference for planning actions in the next cycle. If the results have not improved, then corrective action is taken to overcome them and the study continues in the second cycle with the same steps in the first cycle

C. Research Instruments The instruments used in this study consisted of:

1) Observation Sheet

2) This instrument is used to obtain student activity data.

3) Student Learning Outcome Evaluation Sheet

4) Consists of an evaluation sheet on learning outcomes in the cognitive, affective, and psychomotor domains

5) Field notes Field notes are the teacher's daily notes used to record progress and obstacles encountered during the learning process

D. Data analysis technique Analysis of student activity data Student activity data and analyzed using the formula by Sudijono as follows: Information:

$\mathrm{P}=$ Percentage rate

$\mathrm{F}=$ Frequency of student $/$ teacher activities

$\mathrm{N}$ = Number of students / teachers overall Based on the percentage obtained, the criteria obtained can be grouped as in table

Table 1. Interpretation of Learning Activities

\begin{tabular}{|c|c|c|}
\hline No & \%Interval & Criteria \\
\hline 1 & $0 \%-20$ & Not good \\
\hline 2 & $21 \%-40 \%$ & Not good \\
\hline 3 & $41 \%-60 \%$ & Good enough \\
\hline 4 & $61 \%-80 \%$ & Good \\
\hline 5 & $81 \%-100 \%$ & Very good \\
\hline
\end{tabular}

E. Student Competency Analysis

a. Cognitive Domain Analysis for the cognitive domain of students categorized as complete when they have reached the KKM set by the school, the KKM in SMP Negeri 8 Padang for Natural Sciences is 80 . To analyze the student competency data, descriptive analysis is used. The percentage of students completeness competency both individually for cognitive domains are:

$$
\mathrm{KI}=\frac{\mathrm{SB}}{\mathrm{SM}} \times 100
$$

Information:

$\mathrm{KI}=$ Complete learning completeness individual

$\mathrm{SB}=$ Correct score obtained by students
$\mathrm{SM}=$ Maximum score from the test

Thus, students will be said to be complete if $\mathrm{KI}>80$. Meanwhile, to see the stamina of all students using the formula:

$\mathrm{P}=\frac{\mathrm{JST}}{\mathrm{JSS}} \times 100$

Information:

$\mathrm{KK}=$ Classical completeness

ANN $=$ Number of students completed

JSS $=$ Total number of students

To find the category of completeness of student competencies used classifications like Table 2.

Table 2. Student Competency Criteria

\begin{tabular}{|l|l|}
\hline Interval & Criteria \\
\hline $0-20$ & Not good \\
\hline $21-40$ & Not good \\
\hline $41-60$ & Good enough \\
\hline $61-80$ & Good \\
\hline $81-100$ & Very good \\
\hline
\end{tabular}

Table 2. Student Competency Criteria Interval Criteria 020 Not good 21-40 Not good 41-60 Good enough 61-80 Good 81-100 Very good

b. Affective Domain Analysis Analysis of student competency data in the affective domain uses the formula by Riduwan as follows:

$G=\frac{B}{r} \times 100$

Information:

$\mathrm{G}=$ affective value

$\mathrm{B}=$ Score obtained

$\mathrm{C}=$ Maximum Score

Table 3. Categories of affective domain assessments

$\begin{array}{ll}\text { Interval } & \text { Category } \\ 0-20 & \text { Not good } \\ 21-40 & \text { Not good } \\ 41-60 & \text { Good enough } \\ 61-80 & \text { Good } \\ 81-100 & \text { Very good }\end{array}$

The affective domain is said to be complete when it reaches the good category.

c. Psychomotor Domain Analysis Analysis of student competency data in the psychomotor domain uses the formula by Riduwan as follows:

$$
\mathrm{H}=\frac{\mathrm{B}}{\mathrm{C}} \times 100
$$

Information:

$\mathrm{H}=$ psychomotor value

$\mathrm{B}=$ Score obtained 


\section{$\mathrm{C}=$ Maximum Score}

Table 4. Psychomotor domain assessment

\begin{tabular}{|l|l|}
\hline Interval & Category \\
\hline $0-20$ & Not good \\
\hline $21-40$ & Not good \\
\hline $41-60$ & Good enough \\
\hline $61-80$ & Good \\
\hline $81-100$ & Very good \\
\hline
\end{tabular}

The psychomotor domain is said to be complete when it reaches the good category.

\section{RESULT AND DISCUSSION}

Before carrying out the action the researcher first performed the pre-cycle, at this stage the activities of students during the pre-cycle were included in the less category with values ranging from $49.47 \%$ to $59.37 \%$. Based on observations obtained student achievement in the cognitive domain $58.33 \%$ with an average value of 74.37 is still far below the KKM set by the school. The affective domain shows good results, namely discipline, cooperation, responsibility, confidence, which is in the range of $65.10 \%$ to $75 \%$. The psychomotor domain of students is in the very good category with a range of 88.88 to 96.87 . This student's initial ability is a benchmark for researchers to carry out further activities in order to improve student learning activities and outcomes.

Cycle I consisted of four meetings including the Daily Repeat with the material Interaction of living things with the environment. The first meeting was Monday April 4 2016, the second meeting was Tuesday April 5 2016, the third meeting was Monday 11 April 2016 and the fourth meeting was the Daily Repetition on Tuesday 12 April 2016.

\subsection{Student activities \\ 2.1.1Oral Activity}

Student activities asking questions related to the topic of the lesson averaged $51.38 \%$ enough categories. Student activities in group discussions averaged $90.28 \%$ in the excellent category. Student activities answering questions in class discussions obtained $65.27 \%$ good category. Student activities respond to and issue opinions of $62.50 \%$ in either category.

\subsubsection{Visual Activity}

Activities of students reading books or teaching materials seriously and looking for information in other source books on average $75 \%$ good category.

\subsubsection{Writing activity}

Student activities write ideas about the topic of reading to be read obtained an average percentage of $65.27 \%$ good category. Students recorded the reading comprehension results in the KWL table an average of $63.88 \%$ in both categories. Students make the final conclusions from the results of class discussions $69.44 \%$ good category.
Students doing all the tasks in this first cycle $69.44 \%$ good category. Because there are still activities of students who get enough categories, then this activity must be increased again in the second cycle

\subsection{Student Learning Outcomes}

In the cognitive domain that 18 students the percentage of $75 \%$ is complete and 6 students the percentage of $25 \%$ is incomplete and many are below the expected KKM. This must be increased in cycle II. The results of observations of the affective domain during the learning process by applying the KWL (Know-Want-Learned) strategy through the active bowling campus learning model in cycle I showed good categories for 3 meetings with an average percentage of affective disciplines of $77.73 \%$ good categories, cooperation $80.90 \%$ category very good, responsibility $80.20 \%$ category good, confident $77.45 \%$ category good and persevering $76.76 \%$ with good category. In the psychomotor domain students have gotten very good categories ranging from preparing tools and materials on average $97.92 \%$, doing activities $95.48 \%$ and making a report percentage of $93.05 \%$.

Seeing the results of the first cycle, which is still lacking in terms of student activity and cognitive learning outcomes in accordance with the expected results, it is necessary to make improvements in the implementation of learning in cycle II. Therefore, a reflection of the action is then taken into consideration in the implementation of the second cycle. In this second cycle the teacher must further improve his performance in increasing student activity, correcting any deficiencies in cycle I. The increase in teacher performance and student activity in this second cycle directly influences student learning outcomes. Based on the researcher's discussion with the observer, it is necessary to continue in the second cycle, because seeing students' enthusiasm towards student activities and student competencies that are likely to increase. Student learning outcomes have not yet reached the expected results according to the school KKM target, therefore the action will be continued to the second cycle.

The implementation and improvement of the learning process cycle II consisted of four meetings including the Daily Repeat. The first learning meeting is Tuesday 26 April 2016, the second meeting is Monday 02 May 2016, the third meeting is Tuesday 03 May 2016 and the fourth meeting is Wednesday 04 May 2016.

\subsubsection{Student activities \\ a. Oral Activity}

Activity of students asking questions related to the topic of study an average of $84.72 \%$. Student activities in group discussions averaged $97.22 \%$. Student activities answering questions in class discussions obtained $84.72 \%$. Student activity responding and issuing opinions $84.72 \%$. The overall oral activity of students in the excellent category.

\section{b. Visual Activity}


Activities of students reading books or teaching materials seriously and looking for information in other source books an average of $91.67 \%$ very good category c. Writing activity

Activities of students writing ideas about the topic of reading to be read obtained an average percentage of $88.89 \%$. Students recorded the reading comprehension results on the KWL table an average of $93.05 \%$. Students make the final conclusions from the results of class discussions $91.67 \%$ good category. Students do all the tasks in this second cycle

90.27\% Overall writing activity of students with excellent categories.

\subsubsection{Student learning outcomes}

In the cognitive domain that 24 students are $100 \%$ complete. The results of observations of the affective domain during the learning process by applying the KWL (Know-Want-Learned) strategy through the active bowling

\section{CONCLUSION}

Based on the results of data analysis obtained during the implementation of cycle I and cycle II actions by applying the K-W-L (Know-Want-Learned) strategy through the active bowling campus learning model can increase student learning activities in the learning process. In the

\section{REFERENCES}

[1] Arikunto, S. (2008). Dasar-Dasar Evaluasi Pendidikan. Jakarta: Bumi Aksara.

[2] Arsuman, I. N., \& Andajani, S. J. (2017). Strategi Know - Want to Know - Learned Terhadap Kemampuan Membaca Pemahaman Siswa Tunarungu Kelas III Padang Sekolah Dasar Luar Biasa. Jurnal Pendidikan Khusus.

[3] Dwining Puspitasari, Mitarlis, L. R. (2013). Penerapan Pembelajaran IPA Terpadu Tipe Webbed Dengan Model Pembelajaran Berdasarkan Masalah Tema Hujan Asam Pada Siswa SMPN 1 Manyar Gresik. Jurnal Pendidikan Sains E-Pensa, 01(3), 60-67.

[4] Harahap, R. A., \& Derlina. (2017). Pembelajaran Kooperatif Group Investigation (GI) Dengan Metode Know- Want- Learn (KWL) : Dampak Terhadap Hasil Belajar Fluida Dinamis. Jurnal Ilmiah Pendidikan Fisika

Al- Biruni, 06(2), 149-158. https://doi.org/10.24042/jipfalbiruni.v6i2.1369

[5] Hidayah, D. N., \& Priscylio, G. (2019). Pengembangan Bahan Ajar Mandiri Pokok Bahasan Suhu dan Kalor Menggunakan Software Camtasia. JoTaLP: Journal of Teaching and Learning Physics, 4(1), 65-73. campus learning model in cycle II showed very good categories with an average percentage of affective disciplines of $86.11 \%$, cooperation of $90.62 \%$, responsibility $86.11 \%$, confidence gained $85.41 \%$ and perseverance $84.35 \%$. In the psychomotor domain students have gotten very good categories ranging from preparing tools and materials $100 \%$, doing $98 \%$ activities and making reports $100 \%$.

This shows that there is an increase in student learning activities and outcomes from cycle I to cycle II, thus proving the application of the K-W-L (Know-WantLearned) strategy through the active bowling campus learning model can improve student learning activities and outcomes.

first cycle of student activity gained an average of $68.75 \%$, in the second cycle to $89.86 \%$. and improving student learning outcomes in the cognitive domain in the first cycle was $75 \%$ in the second cycle $100 \%$, the affective domain in the first cycle was $78.61 \%$ and increased in the second cycle $86.52 \%$. The psychomotor domain in the first cycle was $95.48 \%$ and increased in the second cycle to $99.33 \%$. 
[6] Muhadi. (2011). Penelitian Tindakan Kelas. Yogyakarta: Shira Media Nurdjan.

[7] Ogle. (1996). K-W-L: A Teaching Model That Develops Active Reading of Expository Text. The Reading Teacher, 39(6), 564-570.

[8] Priscylio, G., Rochintaniawati, D., \& Anwar, S. (2018). Needs of integrated science textbook for junior high school based on learning style (descriptive research). In International Conference on Mathematics and Science Education (ICMScE). Bandung: Universitas Pendidikan Indonesia.

[9] Rustyaningsih, A. W., Susilaningsih, S., \& Samadhy, U. (2014). Peningkatan Keterampilan Membaca Intensif Melalui Strategi KWL Pada Siswa Kelas V. Joyful Learning Journal, 2(5), 18-24.

[10] Sardiman. (2001). Interaksi dan Motivasi BelajarMengajar. Jakarta: PT Raja Grapindo Persada.

[11] Silberman. (2011). Active Learning :101 Cara Belajar Aktif. Bandung: Nusa Media.

[12] Suryani, A. I. (2018). Pengembangan bahan ajar membaca sekilas berbasis know want learned kelas $\mathrm{v}$

[13] Wardani, D. K., \& Yuliati. (2000). Strategi K-W-L (Know- Want to Know- Learned) Pada Kemampuan Membaca Pemahama Anak Tunarungu Kelas V di SLB B Karya Mulia Surabaya. E-Jurnal Pensa, 1-8.

[14] Yusuf, M. (2012). Penerapan strategi Story Triangle Untuk Meningkatkan Keterampila Menulis Karangan Narasi Siswa Sekolah Dasar. Jurnal Waspada, 2(2), 1-17.

[15] Zuhdi, A., \& Priscylio, G. (2019). Pengembangan Bahan Ajar Fisika Kontekstual Berbasis Inkuiri Terbimbing Pada Materi Rotasi. JoTaLP: Journal of Teaching and Learning Physics, 4(1), 50-64.

[16] Fengjuan. 2010. The Integration of the KnowWant-Learn (KWL) Strategy into English Language Teaching for Non-English Majors. Chinese Journal of Applied Linguistics (Bimonthly) (online) Vol. 33 No. 4

[17] Sudijono, A. 2010. Pengantar Statistik Pendidikan. Jakarta: Raja Grafindo Persada 